\title{
A "Memoryscape" Malayan Union 1946: The Beginning and Rise of Modern Malay Political Culture
}

\author{
Mohd Helmi Abd Rahim ${ }^{1}$, Normah Mustaffa ${ }^{1}$, Fauziah Ahmad ${ }^{1} \&$ N. Lyndon ${ }^{2}$ \\ ${ }^{1}$ School of Media Studies and Communication, Faculty of Social Sciences and Humanities, Universiti \\ Kebangsaan Malaysia, Malaysia \\ ${ }^{2}$ School of Social, Development and Environmental Studies, Faculty of Social Sciences and Humanities, \\ Universiti Kebangsaan Malaysia, Malaysia \\ Correspondence: Mohd Helmi Abd Rahim, School of Media Studies and Communication, Faculty of Social \\ Sciences and Humanities, Universiti Kebangsaan Malaysia, Malaysia. E-mail: mhelmi@ukm.my
}

Received: March 14, 2013 Accepted: April 26, 2013 Online Published: April 28, 2013

doi:10.5539/ass.v9n6p36 URL: http://dx.doi.org/10.5539/ass.v9n6p36

\begin{abstract}
This study researches an experiential and narration-oriented of historiography of an event in Malaysia, the Malayan Union 1946. The Malayan Union was introduced by the British just immediately after the end of the Second World War, the ending of Japanese Occupation in Malaya. In October, 1945, the British announced a bold decision to end their indirect rule in the Malay states through uniting all the states into a Malayan Union under a Governor with executive powers. The proposal also initiated a Malayan form of citizenship which would give equal rights to those who claim Malaya as their homeland. On $1^{\text {st }}$ April 1946, the Malayan Union officially came into existence with Sir Edward Gent as the Governor. The Malays opposed the creation of the Union. Several aspects were seen to be the beginning and rise of modern Malay political culture; (1) the formation of a first Malay political party, (2) defending of the Sultanate as the highest Malay rulers, (3) defending the Malay rights and privileges of their homeland, (4) the reformation of Malay and Malayan politics, (5) the beginning of 'social contract' between the Malay and the non-Malay immigrants and their descendants, (6) the participation of non-Malays in Malayan politics, (7) birth of the independent of Malaya from the British, and (8) the birth of the Constitution of Malaysia. These factors shall be discussed as inscription of historical memory. Nevertheless, the post-Malayan Union that escalates to today's political landscape as somehow sees the event and situation differently as what being seen before. This study will analyze these thoughts through a constructive discussion inferring the future of Malaysian politics of pluralism.
\end{abstract}

Keywords: Malayan Union, British colony, Malay, plural society, United Malay National Organization (UMNO)

\section{Introduction}

The fall of the Malacca kingdom to the Portuguese in 1511 has usually been seen as the end of a chapter in the Malay political history. Nevertheless, the tradition of the Malacca sultanate continued at Pekan Tua in the upper reaches of the Johor River sometime between 1530 and 1536 with the establishment of the royal residence of Sultan Alauddin Riayat Shah II, who became the first of the Malacca dynasty to rule in what became known as the kingdom of Johor (Andaya \& Andaya, 1982). Not much was seen in the Malay politics, until Malacca came under the British rule in 1795, except for a brief period of Dutch control from 1818 until 1824. The political landscape of the Malay then came under the European influence. The Malay, since this period has been seen absorbing and responding to outside influences.

As noted by Munshi Abdullah in his book Hikayat Abdullah (Hill, 1970), one of his main concerns is the change brought about by the European presence, 'the destruction of the old world and the creation of a new'. Munshi Abdullah remembered how those people of Dutch extraction changed their customs and language, their clothing and habits of their race, men and women alike, copying English ways of life (Hill, 1970; Andaya \& Andaya, 1982). The Malay was now caught up by the far-reaching economic and political forces which were drawn Europe and Asia ever closer. The developments began to transform the nature of Malay society. The $19^{\text {th }}$ century saw the establishment of political boundaries and culture which became the basis of modern Malaysia and the growing of socioeconomic distinction of the major ethnic groups. These developments helped define the central concerns of the colonial and independent governments of Malaya/Malaysia well into the twentieth century. This 
change was predominant after the Second World War that ripened the way the Malay looked and fought in the contexts of modern Malay political culture.

This article attempts to discuss the Malayan Union 1946 event, as inscription of historical memory. Nevertheless, the post-Malayan Union that escalates to today's political landscape as somehow sees the event and situation differently as what being seen before. This study analyzes these thoughts through a constructive discussion inferring the later period Malay political culture and Malaysian politics of pluralism.

\section{The Period of the Second World War}

Malaya was invaded by the Japanese on $8^{\text {th }}$ December 1941 and was quickly overrun. In the early years of the occupation, the Japanese were concentrating on a crucial question of how Malaya could best contribute economically to Japan's war effort. By mid-1943, the Malay began to turn against them which made the Japanese changed their focus to greater attention to encouraging Malay nationalism. There were Japanese-organized mass demonstrations, pan-Malayan conferences, language training and administrative education. The Malays began to see themselves as belonging to a Malaya-wide entity, rather than to their individual states, as installed by the British before the war. The growing sense of this united Malay nation, however, weakened the position of the Sultans. Although the Japanese had restored to the Sultans the privileges they had previously enjoyed under the British by early 1943, they did not pay the same deference to the Sultans as did the British colonial rulers. When the Japanese were defeated in 1945, they have laid a strong track in the landscape of political culture among the Malays, especially new ideas of political viewpoint and actions to face the returning British.

The weakened status of the traditional rulers in the Occupation, combined with the Japanese encouragement of Malay nationalism has contributed to the growing importance of new Malay elites who had actually risen in the 1920s and 1930s. These Malay leaders were originated in the early twentieth century in response to the growing influence and presence of both British and the Chinese. At first this nationalism was contained within the various Malay states, but as indirectly encouraged by the Japanese during their Occupation, became Malaya-wide as its appeal transcended traditional political boundaries. Three new elite groups came to vie with the old Malay ruling class as leaders who could best protect Malay interests.

\section{The Rise of the New Elite Groups}

The first of these elite groups arose from the religious reform movement which had its origin from the Islamic Renaissance in the Middle East during the late nineteenth century (Ikhwanul Muslimin's movement). Those who had education from Cairo or the Hejaz brought home this reformist ideas which saw the renovation of Islam as a means of providing Malays to respond to the radical changes brought by the Europeans, Chinese and Indians. Politically, their ideas was an anti-colonial ideas (as in Egypt), and to go against the British with a resolution by the Islamic faith. The main strength of this new elite group was in the urban centers, especially in Penang and Singapore. Somehow, they did gain adherents among religious teachers and others in the Malay rural society. This elite group was opposed by the Malay traditional religious and secular establishments, whom were reinforced by expressing British intention to maintain Malay religion and custom, and the Sultan was the formal head.

Another new elite group was the English-educated administrators and public servants from the traditional Malay ruling classes. The depression period and the administrative reforms of the early 1930s create rivalry among the various ethnic groups engendered a proprietary feeling among Malays that they, being the 'indigenous' people of Malaya, deserved better. This feeling was tapped (as developed before the Japanese Occupation) by the new English-educated Malay elite, whom the Malay people already regarded as legitimate leaders as to their noble birth. They moved confidently among the white men, these young men seemed, to many Malays as the rightful spokesmen for the Malay community.

The third elite group was the secular, Malay-educated intelligentsia, and they were mainly teachers and journalists. They were advocated by an idea of 'Greater Malaya' or 'Greater Indonesia'. They were almost wholly from the Malay peasantry and were therefore critical of the establishment, may it be the British Government, the traditional Malay ruling classes or the English-educated intelligentsia of any ethnic group. They founded the Young Malay Union (KMM) in 1938, an organization very similar to the cultural-political youth groups which had sprung up throughout the Netherlands East Indies. It failed to gain a large following among the conservative Malays, but became the basis for radical Malay political movements after the war. This third elite group was closed to the Japanese as they sought to use the Japanese to achieve their social and political goals. The Japanese saw some value in them, to assure their cooperation for Japanese economic and military plans. However, the surrender of the Japanese on 15 August 1945 brought their plans to a premature end. 
Thus, the Malay political philosophy and views were influenced closely to social and political developments of the world; democracy and rights, Islamic revivalism, youth movements, racial unity and nationalism. As they moved towards modernism in social and politic, the Malays for the first time experienced splitting and disunity, and ideologies were at the beginning stage.

\section{The Situation of the Non-Malays}

The Indians were not treated as well as the Malays during the Occupation but were never brutalized as were the Chinese. Some Indian estate workers were forcefully conscripted for Japanese projects from which many of them never returned (so do some Malays). Nothing much to the feelings of Malayan Indians as under the British too, the mild treatment that they had, result to an ambiguous status. In 1943, the development of nationalism led by Subhas Chandra Boss made the Japanese saw a convenient vehicle for obtaining Indian co-operation for the Japanese war effort. He was brought back to Singapore after an exiled, and proclaimed the Free India (Azad Hind) government and succeeded in enlisting Indians throughout South East Asia in the Indian National Army. The participation of Malayan Indians and other Indian nationalist political organizations, and all of which were strongly anti-British, made the Japanese adopt a relatively lenient stance towards the Indian in Malaya.

Among the major ethnic groups in Malaya during the Occupation, the Chinese received the harshest treatment from the Japanese. The Japanese actions had a great influence of the Manchurian situation, and of the active role of the Kuomintang and Chinese Communist Party sympathizers in Singapore and Malaya who were violently anti-Japanese. Yet the Japanese were finally forced to rely on the Chinese to assure the functioning of the wartime economy. By mid-1944 clubs were even formed for the Chinese in the Strait Settlements to discuss problems in the economy. These efforts, however, never removed the Chinese bitterness towards the Japanese.

While underground movements were formed by various Malay and Indian groups, the main anti-Japanese activity understandably came from the ranks of the Chinese. They comprised the largest component in the MPAJA (Malayan People Anti-Japanese Army), which was in turn dominated by the MCP (Malayan Communist Party). The anti-Japanese resistance in the Occupation bore certain features which came to characterize the later communist insurgency period.

\section{The Chaos of the Immediate Post-War}

The MPAJA was the only armed, well organized group within Malaya. It took over the regional government. The British were forced to rely on them in many areas to maintain law and order. The MPAJA took this opportunity to deal harshly with old enemies and collaborators. Their actions were seen as follows:

1) Although the violence was initiated by ideology, however, quickly became interpreted as an inter-ethnic conflict. The Malays organized themselves under their village secular and religious leaders to fight what they saw as the 'Chinese' MPAJA/MCP.

2) Isolated clashes between Chinese and Malays occurred periodically but never before with such intensity.

3) The Malays beginning to see immediate unfavorable of themselves with the rapid advances of the non-Malay communities but they rarely voiced a violent antagonism towards this group. This time the Malay fears of Chinese domination became intense.

4) Transformed Malay attitude towards the Chinese from one of envy but toleration, to distrust.

5) The Chinese in Malaya became more politicized through the activities of the Chinese Communist Party and the revived Kuomintang.

The communal violence of the post-war years can thus be regarded as logical outcome of the divisive ethnic policies and attitude which had developed gradually over the period of British rule (from the late 1920s and the 1930s), and reached a peak immediately after the war. The implications of the postwar violence were not lost on the people of Malaya.

Independence was still the desirable goal, but there were some who expressed doubts that any independent Malayan government would be able to restrain ethnic enmities one the mediating hands of the colonial power had been removed. Even after the British returned communal killings, and as late as 1948 complete order had still not been restored throughout Malaya.

Amidst of these unbearable incidences, the concern for the future of a Malayan nation resulted in a new type of nationalism, created by a group of nationalists. The philosophy was not associated with any particular ethnic group, nor, with any organization holding out radical solutions for society. As Cheah Boon Kheng (1979:5) puts it,"...to create a real and valid sense of loyalty to Malaya among all races by inspiring in the Malay a national loyalty over and above his naturally loyalty to the Sultans, as symbols of his racial history and traditions, and 
educating him to an adult understanding of his place as a Malayan; and by weaning the non-Malay races from their nostalgia for the homelands of their ancestors, by putting into their hands the real basis of an enduring loyalty." This group of nationalists consisted principally of English-educated, Malaya-born individuals of all groups who believed the future lay with a multi-ethnic united Malaya (including Singapore).

The immediate and timely situation came when the British had rejected their pre-war policy in October 1945 and were working on introducing the Malayan Union policy.

\section{The Malayan Union 1946}

In 1944 the British government adopted a plan proposed by Sir Edward Gent to incorporate the Federated Malay States (FMS), the Unfederated Malay States (UMS), Penang and Melaka into a Malayan Union, while making Singapore a separate crown colony (CAB 66/50, Policy in Regard to Malaya and Borneo). The plan proposing a centralized government comprising these peninsular possessions, to be known as the Malayan Union. The British idea was to conceive the Malay Peninsula under a single government so as to simplify administration. This idea would not be a problem to the new group of nationalists but the content of the Union was all against their philosophy of future Malaya, and this is what they are against for.

The idea of the Union was first expressed by the British on October 1945. Sir Harold McMichael was assigned the task of gathering the Malay state rulers' approval for the Malayan Union in the same month. In a short period of time, he managed to obtain all the Malay rulers approvals. On April 1946 the Malayan Union officially came into existence with Sir Edward Gent as its governor. The capital of the Union was Kuala Lumpur.

As mentioned earlier, the new group of nationalists was against the content of the Malayan Union. The content was as follows:

1) Create a unitary state comprising the FMS, UMS, Penang and Melaka with a central government, a governor, and legislative and executive councils, while making Singapore a separate crown colony. This policy meant the lack of power of all Malay states, including Penang and Melaka. The pretence that the British were merely assisting the Malay rulers to govern their land was finally removed, and this meant to be a British rule. The Malay rulers lost their rights to their land. In the Union plan it was best to maintain Singapore as a separate colony because of fears that Malay opposition to Singapore would prevent acceptance of the Union, besides its strategic and economic values. However, the Malay nationalists and leaders feared being swamped by Singapore's large Chinese population (the old fear was being materialized).

2) The Malay Sultans were to retain their positions but sovereignty was to be transferred to the British Crown. This means that the Sultans were conceded all their powers to the British Crown, except of religion and customs matters. Moreover, although the State Councils were still kept functioning, it lost the limited autonomy that they enjoyed as they administered some local and less important aspects of government, and the Federal Government will be controlling the vital aspects. Also, British Residents will be replacing the Sultans as the head of the State Councils meant that the political status of the Sultan was greatly reduced. The Sultans were deemed to be the protectors of the Malays.

3) The way Sir Harold McMichael did in getting the approval of the Malay Sultans was criticized. The reasons for the rulers agreement, despite the loss of political power that it entailed for the Malay rulers, has been much debated; the consensus was that as the Malay rulers were of course resident during the Japanese Occupation, they were opened to the accusation of collaboration, and that they were threatened with the dethronement (Ariffin Omar, 1993; Goto, 2003). The approval was given, though it was with utmost reluctance.

4) All citizens of the new Malayan Union would have equal rights, including admission to the administrative civil service. The Malay protested to this new scheme, questioning their rights to be indigenous to the land and they deserved the privileges, as compared to the immigrants (Chinese and Indians).

5) Malayan citizenship was to be extended to all without discrimination as to race or creed. The Malayan Union gave equal rights to people who wished to apply for citizenship. The late 1920s and the 1930s fear for the Malays of Chinese dominance (and other immigrants) were being convinced by the Malayan Union policy. By that time, there was an increase in Chinese schools in Malaya using kuo yu (mandarin) and teaching subjects more orientated to China than Malaya. There were attempts by the Chinese to increase their own participation in government, further weakened Malay authority, which was already happening due to decentralization policy by British measures. The census of 1931 had already revealed, for the first 
time, there were more Chinese $(1,709,392)$ than Malays $(1,644,173)$. The opposition of the Malays towards the granting of citizenship to non-Malay immigrants and their descendents-especially the Chinese, not only because of their racial and religious difference but also because their economic dominance was seen a threat to the Malays. The post-war situation of the MPAJA/MCP actions was another factor than the Malays would never forget. The fact that people were allowed to hold dual nationalities meant there was a possibility that the Chinese and Indians would be loyal to their home country, rather than Malaya. As for the Malays, Malaya was their only homeland and motherland.

6) The Malayan Union was in favor of the Chinese and other non-Malay immigrants. The British believed that the Chinese and Indian communities had remained generally loyal to the colonial power. Despite the fact that two Malay battalions had fought with the British at Singapore in 1942, and later the Malay dominated Force 136 were giving resistance to the Japanese, the refusal of the Sultans to evacuate with the British during the Japanese invasion, and the activities of PETA brought disfavor on the entire Malay community. By contrast, the Malays believed they were defending their country, and the rulers were to be with their people. The Malays opposing the Malayan Union were also in that spirit, loyalty to their rulers and defend a land that was belonged to them.

7) Retired British members of the Malayan Civil Service and Malay leaders led the attack on the Union plan, accusing MacMichael of using 'methods of intimidation' to obtain the Malay rulers agreement. Old Malayan lobby in parliament joined by important ex-Malayan Civil Service Officers such as Swettenham, G. Maxwell, Winstedt, Clementi and Guillemard. They even said that it went against the principles of the Atlantic Charter. This inspired the Malays to oppose the Malayan Union. They even encouraged Malay opposition to the Malayan Union.

Contrary to British expectations, the normally apathetic Malay population rose as one in strong protest to this new scheme, called the Malayan Union. Nor were the Chinese and Indian communities particularly enthusiastic and in fact even criticized some of the provisions. The Malays even advanced by a new political force by forming the United Malays National Organization (UMNO) on $1^{\text {st }}$ March 1946 led by Dato' Onn Jaafar the Chief Minister of Johor, as its first president.

After the inauguration of the Malayan Union, the Malays, under UMNO, continued opposing the Malayan Union. They utilized civil disobedience as a means of protest by refusing to attend the installation ceremonies of the British Governor. They refused to participate in the meetings of the Advisory councils. Malay participation in the government bureaucracy and the political process had totally stopped. The British were forced to consider the opinions of the major races before making amendments to the Union. The opposition was so effective than the plan was never brought into effect. It was finally revoked in its entirety after $1^{\text {st }}$ February 1948 , and the Federation of Malaya was created.

In the Federation, the sovereignty of the Sultans, the individuality of the States, and Malay special privileges were upheld. A strong central government was established with legislative power, though the states were assured jurisdiction over a number of important matters. A High Commissioner was appointed, in replacement of the Governor, as the symbolic gesture that authority was from the Sultans rather than the British Crown. The Federation was a victory for the Malays.

The Federation was greeted with some dismay among other ethnic groups. The Chinese, in particular, felt betrayed since they believed that they had sacrificed more and had been the most loyal towards the British during the recent war. They tend to forget that the land (Malaya) belonged to the Malays and of their immigrant's history. The positive implication, where some did not realize, that they had the feelings that there were Malayan Chinese who wanted to be part of Malaya as their homeland. Some of the discontented Chinese now saw their only hope for a just society in the promises of the Malayan Communist Party (MCP) which later ended in a long terrorist war and a military one, even after the independence of Malaya.

\section{Birth of the Nation}

The opposition, dissolution of the Malayan Union 1946 and the creation of the Federation of Malaya led to the beginning and rise of modern Malay politics and building a Malayan political culture after that, and realizing it until today. Some aspects were to be seen:

1) The formation of a first strong Malay political party accepted by most Malays the United Malays National Party (UMNO) and became a platform for the Malays to gain independence of Malaya. This represented the reformation of Malay and Malayan politics from their traditional form to modern party-based politics. The party brought unity among the Malays with clear, identified and achievable goals. 
The formation of the political party again, showed the Malay's acceptance of democracy and proven later on, in the process of the struggle for independence.

2) Nevertheless, the Malays were straight out defending their Sultans as the highest rulers. The tradition of identifiable of the Malay culture and civilization was always kept as of the Malacca Sultanate system established in 1400. Most of all, it was not actually to keep the nostalgia, as to the Malays, the Sultans were their dignity, unity and their leaders. Defending the sultans, meant to defend Malays, their religion Islam and the motherland.

3) The Malays had won defending their rights and privileges of their motherland, Malaya. They were not prepared to be 'beggars' (as what been said) in their motherland, lost all powers of economy, administrative, politics and rights to their motherland. They won of opposing to the Malayan Union.

4) Most Chinese began to realize that Malaya ought to be their homeland. They could not achieve this by fighting the British and the Malays. Cooperation and negotiation deemed to be important. The MCA (Malayan Chinese Association) was established in February, 1949, partially in response to UMNO's founding three years earlier. The forging of a political alliance in 1952 between UMNO and the MCA (in a local election), a new political alliance was born between the Malays and the Chinese. The MCP lost their ground and influence gradually. With the British announcement of their intention to grant independence to Malaya, the MCP program lost its momentum and communist hopes for control quickly faded. The alliance was increasingly viewed as the only hope for a viable independent Malayan government (Stubbs, 1979). The incorporation of the MIC (Malayan Indian Congress) into the Alliance as a full-fledged partner in 1954 was viewed by the British government as a positive step towards the creation of a united Malayan nation. In the federal elections of July 1955, the Alliance demonstrated its overwhelming support by obtaining 81 percent of the vote, and 51 of the 52 contested seats (Means, 1976). The unity of all races had emerged which later gave them the independence with an astonishing 'social contract'.

5) The early efforts by leaders of different Malay elite groups and communities to work together were tentative and temporary. The promoters, such as the AMPAJA-PUTERA, GLU-MCP and MRLA-MCP collaboration and the CLC had to reconcile almost irreconcilable positions involving communal issues. But these attempts laid the groundwork for future inter-ethnic partnership that were more sustained (Lee, 2010).

\section{Conclusion}

This article attempts on 'memoryscape', through a constructive, critical discussion of an event which inferred to the present day of Malay politics and of the Malaysian politics of pluralism at present. The study researches an experiential and narration-oriented of historiography of an event, the Malayan Union 1946. The study discusses the Malayan Union 1946 event as inscription of historical memory. Several aspects were seen to be the beginning and rise of modern Malay political culture. Somehow, the Malayan Union event escalates to the building and sustaining of today's Malaysia political landscape. The Malayan Union 1946 has shaped the present politics of Malaysia in the framework of a federal representative democratic constitutional monarchy, having the King (Yang Di Pertuan Agong) as the head of state and the Prime Minister the head of government. Today, Malaysia has a multi-party system since the first election in 1955, for the Federal Legislative Council of Malaya. Ever since, it has always been the Alliance Party (Parti Perikatan) coalition. Subsequently, from 1973 onwards the National Front (Barisan Nasional) coalition was formed. The coalition still consists of the United Malay National Organization (UMNO), Malaysian Chinese Association (MCA), Malaysian Indian Congress (MIC), and 11 other political parties. Lately, the opposition parties have gained popularity and thus developed another interesting development of Malaysian politics. It is interesting and fruitful to remember the past, and to construct the future.

\section{References}

Andaya, B. W., \& Andaya, L. Y. (1982). A History of Malaysia. London: The Macmillan Press Ltd.

Cheah, B. K. (1979). The masked comrades: a study of the Communist United Front in Malaya 1945-48. Singapore: Oxford University Press.

Goto, K. (2003). Tensions of empire: Japan and Southeast Asia in the colonial and postcolonial world. Athens: Ohio University Press.

Hill, A. H. (1970). Hikayat Abdullah. Kuala Lumpur: Dewan Bahasa dan Pustaka.

Lee, K. H. (2010). Road to independence: birth of UMNO and Malayan Union. Retrieved July 13, 2011, from http://english.cpiasia.net/index.php?option=com_content\&view=article\&id=1855 
Means, G. P. (1976). Malaysian Politics. London: Oxford University Press.

Omar, A. (1993). Bangsa Melayu: Malay concepts of democracy and community, 1945-1950. Kuala Lumpur: Oxford University Press.

Stubbs, R. (1979). The United Malay National Organization, the Malayan Chinese Association, and the Early Years of the Malayan Emergency, 1948-1955. JSEAS, 10, 85-86. 